\title{
Growth, Yield and Yield Contributing Factors of Rice Crop as Influenced by Different Level and Methods of Irrigation in Tarai Region of Uttarakhand, India
}

\author{
Vikas Sharma ${ }^{1 *}$, Priyanka Gunjan², Yadvendra Pal Singh ${ }^{1}$ and P.K. Singh ${ }^{1}$ \\ ${ }^{1}$ Department of Irrigation and Drainage Engineering, G.B Pant University of Agricultural \\ and Technology, Pantnagar, India \\ ${ }^{2}$ Indian Institute of Technology (IIT), Roorkee, India \\ *Corresponding author
}

\section{A B S T R A C T}

\section{Keywords \\ Aqua Crop model, Water use Efficiency, Subsurface drip irrigation \\ Article Info \\ Accepted: \\ 10 March 2019 \\ Available Online: \\ 10 April 2019}

The present study was undertaken with a view to study the effect of different level of irrigation on biometric parameters of rice crop such as growth, yield and yield attributes and water use efficiency under surface and subsurface drip irrigation. The results shows that the biometric parameters such as plant height, number of tillers per plant, plant dry matter and LAI for rice crop were found maximum in the treatments $\mathrm{T}_{3}$ (subsurface drip) and $\mathrm{T}_{8}$ (conventional irrigation). Water supply to the crops was significantly higher in the treatment $\mathrm{T}_{8}$ as compared to other treatments. The crop yield was found to be maximum in treatments $T_{8}$ followed by $T_{7}$ and $T_{3}$. Whereas, the water use efficiency for treatments under drip irrigation was significantly superior to the treatments under conventional irrigation.

\section{Introduction}

The available fresh water resources in the world are constant and the population is continually increasing, this available water per capita will continue to decrease resulting in stress or water scarcity in some areas.

Rice (Oryza sativa) is the most important human food crop in the world, directly feeding more people than any other crop. Rice has also fed more people over a longer time than has any other crop. It is spectacularly diverse, both in the way it is grown and how it is used by humans. This is the staple food of those people which living in the eastern and the southern parts of the country, particularly in the areas having over $150 \mathrm{~cm}$ annual rainfall. As of 2009 world food consumption of rice was 531.61 million metric tons of paddy equivalent $(354,60281$ of milled equivalent), while the remote largest consumers were China consuming 156.31 million metric tons of paddy equivalent (29.4 percent of the world consumption) and India consuming 123.5 million metric tons of paddy equivalent $(23.28 \%$ of the world consumption) (FAO 2012). Drip irrigation is a 
type of micro- irrigation that has the potential to save water and nutrients by allowing water to drip slowly to the roots of plants, either from above the soil surface or buried below the surface. The goal is to place water directly into the root zone and minimize evaporation rate. Drip irrigation systems distribute water through a network of direction and flow control valves, pipes, tubing, and emitters or drippers. Depending on how well designed, installed, maintained, and operated it is, a drip irrigation system can be more efficient than other types of irrigation systems, such as surface irrigation or sprinkler irrigation.

The main objectives of this study to investigate growth, yield and yield contribute factors as influenced by different level and method of irrigation.

\section{Materials and Methods}

\section{Study area, climate and soil characteristics}

The present study was conducted at G.B. Pant University of Agriculture and Technology, Pantnagar $\left(29^{\circ} \mathrm{N}\right.$ latitude, $79^{\circ} 30^{\prime} \mathrm{E}$ longitude and $243.83 \mathrm{~m}$ above mean sea level) in Uttarakhand state of India which comes under Tarai region, located in foothills of the Himalayas. The study area comes under Agro- climatic zone 14 and 9. The experimental fields of 1000 square meter at the Vegetable Research Centre (VRC), G.B Pant University of Agriculture and Technology Pantnagar, Uttarakhand was selected to conduct various field experiments. The experimental field has drip irrigation as well as surface irrigation facility. The meteorological data such as temperature, relative humidity, wind speed, rainfall, pan evaporation and sunshine hours during the crop period was acquired from the meteorological observatory located at Crop Research Centre (CRC), Pantnagar which is 5 $\mathrm{km}$ away from the experimental site. The average annual rainfall was $1400 \mathrm{~mm}$ with the monsoon season generally from June to September month. The summer is too dry and hot, and the winter is very cold. The dry season starts from November and ends in May. The mean monthly temperature ranges from $5^{\circ} \mathrm{C}$ to $25^{\circ} \mathrm{C}$ while the mean maximum temperature varies from $20^{\circ} \mathrm{C}$ to $40^{\circ} \mathrm{C}$. The experimental site consists of silty clay loam with sand (14\%), silt (54\%) and clay (32\%). The average bulk density of the experimental site was determined using core sampler. The average bulk density was found to be 1.45 $\mathrm{g} / \mathrm{cm}^{3}$. The soil moisture content before and after irrigation and at field capacity was determined by soil moisture meter (TDR 300) and calibrated with gravimetric method at regular interval of time. The field capacity was found to be 42 percent by volume basis.

\section{Drip irrigation scheduling of rice crop}

The crop water requirement was calculated by following formula as given in INCID, (1994). The total water applied to the rice crop is calculated as:

$\mathrm{V}=\sum\left(\mathrm{E}_{\mathrm{p}} \times \mathrm{K}_{\mathrm{p}} \times \mathrm{K}_{\mathrm{c}} \times \mathrm{S}_{\mathrm{p}} \times \mathrm{S}_{\mathrm{r}} \times \mathrm{WP}+\mathrm{ER}\right)$

Where,

$\mathrm{V}=$ estimated crop water requirement at $100 \%$ water use level, litre/day/plant

Epan $=$ Pan Evaporation, $\mathrm{mm} /$ day $\mathrm{Kp}=$ Pan coefficient

$\mathrm{Kc}=$ Crop coefficient

$\mathrm{Sp}=$ Plant to plant spacing, $\mathrm{m} \mathrm{Sr}=$ Row to row spacing, $\mathrm{m}$

$\mathrm{Wp}=$ Percentage wetted area, 90\% ER = Effective rainfall, $\mathrm{mm}$

In this study calculation of crop coefficient, $\mathrm{K}_{\mathrm{c}}$, for rice crop was done on the basis of Agromet Advisory Service Bulletin, GBPUA\&T, Pantnagar The value of crop 
coefficient for initial stage $\mathrm{K}_{\mathrm{c}}$ nit was taken as 0.8 , for mid stage $K_{c}$ mid was taken as 1.7 and for end stage it was taken as $\mathrm{K}_{\mathrm{c}}$ end as 0.7 .

Based on USDA. S.C.S method the effective rainfall (ER) is calculated on monthly basis as:

$\mathrm{ER}=\mathrm{P}_{\mathrm{t}} \frac{125-0.2 \times \mathrm{Pt}}{[125] \text { for }} \mathrm{Pt}<250 \mathrm{~mm}$ Where, $\mathrm{P}_{\mathrm{t}}$ - total rainfall, $\mathrm{mm}$

The drip irrigation system with a mainline of a PVC pipe of $40 \mathrm{~mm}$ diameter having wall thickness of $1.8 \mathrm{~mm}$ and pressure rating up to $6 \mathrm{~kg} / \mathrm{cm}^{2}$ was laid.

The lateral turbo line having $16 \mathrm{~mm}$ diameter was provided with drippers of $1.3 \mathrm{lph}$ discharge capacity with minimum pressure of $1 \mathrm{~kg} / \mathrm{cm}^{2}$ spaced at $30 \mathrm{~cm}$. In this study drip lines (lateral) were laid parallel to the crop rows and one drip line served two rows of crop.

The duration of water application to each treatment was controlled with the help of delivery valves provided at inlet of each laterals. Under drip irrigation treatments soil moisture was maintained near field capacity with the help of frequently application of water at 3-7 days interval.

\section{Experimental treatments for rice crop}

T1: V - Volume of water application under surface drip irrigation in DSR planted at 20 cm row spacing

T2: 1.2V - Volume of water application under surface drip irrigation in DSR planted at 20 $\mathrm{cm}$ row spacing

T3: 1.2V - Volume of water application under subsurface drip irrigation in DSR planted at $20 \mathrm{~cm}$ row spacing

T4: V - Volume of water application under surface drip irrigation in DSR planted at 15 $\mathrm{cm}$ row spacing

T5: 1.2V - Volume of water application under surface drip irrigation in DSR planted at 15 $\mathrm{cm}$ row spacing

T6: $1.2 \mathrm{~V}$ - Volume of water application under subsurface drip irrigation in DSR planted at $15 \mathrm{~cm}$ row spacing

T7: Surface irrigation (soil moisture maintained at saturation) in DSR planted at 20 $\mathrm{cm}$ row spacing

T8: Conventional flood irrigation (Standing Water) in TPR planted at $20 \mathrm{~cm}$ row spacing

Test crop, preparation of experimental plot, fertilizer application and fertigation

Rice (Oryza sativa), variety HKR-47 was selected as test crop for study. Deep ploughing $(20-25 \mathrm{~cm})$ of field was done with soil turning plough. In subsurface drip irrigation treatments, lateral (turbo line) were laid at $20 \mathrm{~cm}$ below ground surface. At the inlet of drip line (turbo line) lateral valve were provided to start and stop the irrigation.

With the row spacing of $20 \mathrm{~cm}$ and $15 \mathrm{~cm}$ the rice seeds were directly sown on $22^{\text {th }}$ of June 2015 in direct seeded rice (DSR) treatments. Later the transplantation of nursery raised rice seedlings were done on $15^{\text {th }}$ July 2015 with the row spacing of $20 \mathrm{~cm}$ in transplanted rice treatment replications. Recommended dose of $\mathrm{N}: \mathrm{P}_{2} \mathrm{O}_{5}: \mathrm{K}_{2} \mathrm{O}, 120: 60: 40 \mathrm{~kg} / \mathrm{ha}$ were supplied during the crop period which was based on soil analysis.

At the time of sowing and just before transplanting, the $25 \%$ of recommended dose of nitrogen and total quantities of $\mathrm{P}_{2} \mathrm{O}_{5}$ and $\mathrm{K}_{2} \mathrm{O}$ along with $25 \mathrm{~kg} / \mathrm{ha}$ of zinc $(\mathrm{Zn})$ were applied. The harvesting of the crop was started on $31^{\text {th }}$ October 2015. The harvesting 
was finished by $2^{\text {nd }}$ November, 2015. From each plot, the crop and straw yield was recorded separately and then converted to per hectare basis.

\section{Biometric observations recorded in rice crop}

Five plants were randomly selected from each replication and selected plants were tagged by aluminium tag for identification. For taking biometric observations, different parameters of vegetative growth such as plant height, number of tillers per plant, number of shoots per $\mathrm{m}^{2}$, leaf area index, plant dry matter and yield and yield contributing characters were recorded at 30, 60, 90 DAS and at harvest.

\section{Statistical analysis}

In this study analysis of variance technique was used to analyse the experimental data to randomized block design with the help of computer. The critical differences at 5\% level of probability were calculated for testing the significance of difference between the treatments.

\section{Results and Discussion}

In this study effects of treatments on all the characters were found to be significant.

The highest average plant height (Table 4.1) at 30 and 60 DAS was recorded for $\mathrm{T}_{3}(1.2 \mathrm{~V}$ Volume of water application under subsurface drip irrigation in DSR planted at $20 \mathrm{~cm}$ row spacing) with value of $36 \mathrm{~cm}$ and $70 \mathrm{~cm}$, respectively. While average plant height at 90 days after sowing and at harvest was found to be highest for $T_{8}$ (Conventional flood irrigation (Standing Water) in TPR planted at $20 \mathrm{~cm}$ row spacing) with value of $96 \mathrm{~cm}$ and $103 \mathrm{~cm}$, respectively. The result revealed that the significant influence of sub surface drip irrigation with $20 \mathrm{~cm}$ row spacing over submerged irrigation at 30 and 60 DAS on plant height while the TPR with saturated level of irrigation under surface irrigation showed significant influence on plant height entire the growing period of crop.

\section{Number of tillers per plant}

At 30 DAS the number of tillers per plant was found to be almost similar for all the treatments except treatments $\mathrm{T}_{6}, \mathrm{~T}_{7}, \mathrm{~T}_{8}$ (Table 3.2).

At 60, 90 DAS and at harvest the highest number of tillers per plant was recorded for with value of $12,11,10$, respectively. Thus, result showed that the number of tillers per plant in transplanted rice (TPR) was significantly superior to direct seeded rice (DSR).

\section{Leaf Area Index (LAI)}

The highest leaf area index at 30 DAS was recorded for the treatment $\mathrm{T}_{8}\left(1.16 \mathrm{~m}^{2} \mathrm{~m}^{-2}\right)$ followed by $\mathrm{T}_{7}\left(1.1 \mathrm{~m}^{2} \mathrm{~m}^{-2}\right)$. AT 60,90 , and at harvest, the highest LAI was recorded again in $\mathrm{T}_{8}$ followed by $\mathrm{T}_{7}$ and $\mathrm{T}_{1}$ (Table 3.3). Thus, result showed that TPR with submerged irrigation was significantly superior to DSR under drip. This result revealed that the plant leaf growth was affected by water and moisture availability.

\section{Plant dry matter}

At 30, 60 and 90 DAS the plant dry matter was recorded maximum for treatment $\mathrm{T}_{5}(182$ $\left.\mathrm{g} \mathrm{m}^{-2}\right), \mathrm{T}_{3}\left(463 \mathrm{~g} \mathrm{~m}^{-2}\right)$ and $\mathrm{T}_{6}\left(1946 \mathrm{~g} \mathrm{~m}^{-2}\right)$, respectively. At harvest the plant dry matter was found to be highest for the treatment $T_{8}$ (2070 $\mathrm{g} \mathrm{m}^{-2}$ ) (Table 3.4).

This result showed that TPR with submerged irrigation was significantly superior to DSR under drip and DSR with saturated level of irrigation. 


\section{Yield and yield contributing characters}

The number of productive tillers/hill and panicle length were recorded highest for treatment $T_{8}$ followed by $T_{2}$ and $T_{3}$. The analysis of the data revealed that the number of panicles and grains per plant were recorded highest for the treatment $\mathrm{T}_{8}$ followed by $\mathrm{T}_{7}$.

The weight of 1000 grains was highest for treatment $\mathrm{T}_{8}$ with a value of $40.8 \mathrm{gm}$ followed by $\mathrm{T}_{7}$ and $\mathrm{T}_{3}$ (Table 3.5) Thus, this result showed the method of irrigation such as surface irrigation, surface drip irrigation and subsurface drip irrigation significantly influenced the crop yield and all yield contributing characters. Similar result was also reported by Ayars et al., (1999) based on his study on subsurface drip irrigation of row crops: a review of 15 years of research at the Water Management Research Laboratory. The result revealed that the grain yield was observed maximum for the treatment $\mathrm{T}_{8}$ (7.9 $\mathrm{t} / \mathrm{ha}$ ) followed by treatment $\mathrm{T}_{7}(7.1 \mathrm{t} / \mathrm{ha})$ and treatment $\mathrm{T}_{3}(6.9 \mathrm{t} / \mathrm{ha})$ and minimum for treatment $\mathrm{T}_{4}(5.4 \mathrm{t} / \mathrm{ha})$. Similar results were reported by other researchers (Tabbal et al., 2002, Bouman et al., 2005) between continuous and intermittent irrigation. The straw yield was observed maximum for the treatment $\mathrm{T}_{8}(12.1 \mathrm{t} / \mathrm{ha})$ followed by treatment $\mathrm{T}_{7}(11.1 \mathrm{t} / \mathrm{ha})$ and the minimum for $\mathrm{T}_{1}$ (8.6 t/ha). In this study harvesting index was recorded highest for the treatment $\mathrm{T}_{3}(42.5 \%)$ and lowest for treatment $\mathrm{T}_{4}(35.5 \%)$. Thus, the overall result revealed that treatments $\mathrm{T}_{8}$ (Conventional flood irrigation (Standing Water) in TPR planted at $20 \mathrm{~cm}$ row spacing) and $\mathrm{T}_{3}(1.2 \mathrm{~V}$ - Volume of water application under subsurface drip irrigation in DSR planted at $20 \mathrm{~cm}$ row spacing) were significantly superior to other treatments.

The effect of irrigation regimes and method of irrigation on water use efficiency (WUE) was significant $T_{1}$ to $T_{8}$ with 0.018 to 0.0621 t/ha- $\mathrm{cm} \mathrm{m}$ (Table 3.6). The water use efficiency was found to be highest for the treatment $\mathrm{T}_{3}$ with a value of $0.0621 \mathrm{t} / \mathrm{ha}-\mathrm{cm}$, followed by treatment $\mathrm{T}_{6}$ with a value of $0.0620 \mathrm{t} / \mathrm{ha}-\mathrm{cm}$. Surface irrigation under treatment $\mathrm{T}_{8}$ i.e. TPR with continuous soil submergence produce lowest WUE but in the treatment $\mathrm{T}_{7}$ i.e. surface irrigation in DSR with saturated soil increases the WUE (Table 4.9). In this study the amount of water needed to grow one $\mathrm{kg}$ of rice was found to be lowest for treatment $\mathrm{T}_{3}$ with a value of 1607 litres of water, followed by treatment $T_{6}$ with a value of 1611 litres of water and highest for treatment $\mathrm{T}_{8}$ with a value of 5508 litres of water. Thus, the overall result showed that the effective use of water as well as effective water management under surface and subsurface drip irrigation over surface irrigation.

Field investigations was undertaken to investigate the growth yield and yield contribute factor as influenced by different level and method of irrigation at the experimental farm of Vegetable Research Centre, GBPUA\&T, Pantnagar, Uttarakhand. The highest average plant height at 30 and 60 DAS was recorded for $T_{3}(1.2 \mathrm{~V}$ - Volume of water application under subsurface drip irrigation in DSR planted at $20 \mathrm{~cm}$ row spacing) with a value of $36 \mathrm{~cm}$ and $70 \mathrm{~cm}$, respectively. While average plant height at 90 days after sowing and at harvest was found to be highest for $T_{8}$ (Conventional flood irrigation (Standing Water) in TPR planted at $20 \mathrm{~cm}$ row spacing) with a value of $96 \mathrm{~cm}$ and $103 \mathrm{~cm}$, respectively. At 30 DAS the number of tillers per plant was found to be almost similar for all the treatments except treatments $\mathrm{T}_{6}, \mathrm{~T}_{7}, \mathrm{~T}_{8}$. At 60, 90 DAS. At harvest, the highest number of tillers per plant was recorded for $T_{8}$ (Conventional flood irrigation (Standing Water) in TPR planted at $20 \mathrm{~cm}$ row spacing) with a value of 12,11 , 10 , respectively. 
Table.1 Effect of various treatments on plant height of rice crop $(\mathrm{cm})$ at different stages of crop growth

\begin{tabular}{|c|c|c|c|c|}
\hline \multirow[t]{3}{*}{ Treatment } & \multicolumn{4}{|c|}{ Plant Height (cm) } \\
\hline & \multicolumn{4}{|c|}{ Days after sowing (DAS) } \\
\hline & 30 & 60 & 90 & At Harvest \\
\hline $\mathbf{T}_{1}$ & 29 & 68 & 82 & 93 \\
\hline $\mathbf{T}_{2}$ & 34 & 66 & 84 & 90 \\
\hline $\mathbf{T}_{3}$ & 36 & 70 & 84 & 91 \\
\hline $\mathbf{T}_{4}$ & 34 & 68 & 82 & 92 \\
\hline $\mathbf{T}_{5}$ & 34 & 66 & 86 & 90 \\
\hline $\mathbf{T}_{6}$ & 33 & 67 & 78 & 87 \\
\hline $\mathbf{T}_{7}$ & 33 & 66 & 92 & 100 \\
\hline $\mathbf{T}_{8}$ & 31 & 70 & 96 & 103 \\
\hline $\mathrm{CD}(\mathrm{P}<\mathbf{0 . 0 5})$ & 6.3 & 6.5 & 9.85 & 10.1 \\
\hline SEM ( \pm$)$ & 0.83 & 1.06 & 2.1 & 1.5 \\
\hline CV (\%) & 7.1 & 4.4 & 7 & 5 \\
\hline
\end{tabular}

Table.2 Effect of various treatments on number of tillers per plant of rice crop at different stages of crop growth

\begin{tabular}{|c|c|c|c|c|}
\hline \multirow{2}{*}{ Treatment } & \multicolumn{5}{|c|}{ Number of tillers per plant } \\
\hline \multirow{2}{*}{$\mathbf{T}_{\mathbf{1}}$} & $\mathbf{5 0}$ & $\mathbf{6}$ & $\mathbf{6 0}$ & At harvest \\
\hline $\mathbf{T}_{\mathbf{2}}$ & 4 & 10 & 9 & $\mathbf{8}$ \\
\hline $\mathbf{T}_{\mathbf{3}}$ & 4 & 9 & 9 & $\mathbf{9}$ \\
\hline $\mathbf{T}_{\mathbf{4}}$ & 4 & 8 & 8 & $\mathbf{7}$ \\
\hline $\mathbf{T}_{\mathbf{5}}$ & 4 & 9 & 8 & $\mathbf{8}$ \\
\hline $\mathbf{T}_{\mathbf{6}}$ & 4 & 7 & 7 & $\mathbf{6}$ \\
\hline $\mathbf{T}_{\mathbf{7}}$ & 3 & 9 & 8 & $\mathbf{7}$ \\
\hline $\mathbf{T}_{\mathbf{8}}$ & 3 & 8 & 7 & $\mathbf{7}$ \\
\hline $\mathbf{C D}(\mathbf{P}<\mathbf{0 . 0 5})$ & 5 & 12 & 11 & $\mathbf{1 0}$ \\
\hline $\mathbf{S E M}(\mathbf{(})$ & 1.1 & 4.9 & 1.6 & $\mathbf{1 . 2}$ \\
\hline $\mathbf{C V}(\boldsymbol{\%})$ & 0.23 & 0.70 & 0.56 & $\mathbf{0 . 4 5}$ \\
\hline
\end{tabular}


Table.3 Effect of various treatments on leaf area index (LAI) of rice crop at different stages of crop growth

\begin{tabular}{|c|c|c|c|c|}
\hline \multirow[t]{3}{*}{ Treatment } & \multicolumn{4}{|c|}{ Leaf Area Index (LAI) } \\
\hline & \multicolumn{4}{|c|}{ Days After sowing (DAS) } \\
\hline & $\begin{array}{l}3 \\
\mathbf{0}\end{array}$ & 60 & 90 & At Harvest \\
\hline $\mathbf{T}_{1}$ & 0.95 & 2.12 & 4.57 & 3.4 \\
\hline $\mathbf{T}_{2}$ & 0.91 & 2.08 & 4.31 & 3.22 \\
\hline $\mathbf{T}_{3}$ & 0.87 & 2 & 4.21 & 3.02 \\
\hline $\mathbf{T}_{4}$ & $\begin{array}{c}0.90 \\
5\end{array}$ & 2.02 & 4.35 & 3.06 \\
\hline $\mathbf{T}_{5}$ & 0.86 & 2.01 & 4.2 & 3.15 \\
\hline $\mathbf{T}_{6}$ & 0.92 & 2.07 & 4.32 & 3.1 \\
\hline $\mathbf{T}_{7}$ & 1.1 & 2.2 & 4.6 & 3.25 \\
\hline $\mathbf{T}_{8}$ & 1.16 & 2.92 & 4.78 & 3.9 \\
\hline $\mathrm{CD}(\mathrm{P}<0.05)$ & 0.12 & 0.18 & 0.32 & 0.46 \\
\hline SEM ( \pm$)$ & 0.05 & 0.12 & 0.10 & 0.10 \\
\hline CV $(\%)$ & 14.9 & 16.4 & 6.40 & 8.70 \\
\hline
\end{tabular}

Table.4 Effect of various treatments on plant dry matter of rice crop at different stages of crop growth

\begin{tabular}{|c|c|c|c|c|}
\hline \multirow[t]{3}{*}{ Treatment } & \multicolumn{4}{|c|}{ Plant dry matter $\left(\mathrm{g} \mathrm{m}^{-2}\right)$} \\
\hline & \multicolumn{4}{|c|}{ Days after sowing (DAS) } \\
\hline & 30 & 60 & 90 & At Harvest \\
\hline $\mathbf{T}_{1}$ & 113 & 362 & 1341 & 1778 \\
\hline $\mathbf{T}_{2}$ & 147 & 411 & 1427 & 1890 \\
\hline $\mathbf{T}_{\mathbf{3}}$ & 122 & 463 & 1229 & 1759 \\
\hline $\mathbf{T}_{4}$ & 155 & 419 & 1680 & 2315 \\
\hline $\mathbf{T}_{5}$ & 182 & 415 & 1890 & 2472 \\
\hline $\mathbf{T}_{6}$ & 158 & 373 & 1946 & 2560 \\
\hline $\mathbf{T}_{7}$ & 134 & 398 & 1195 & 1640 \\
\hline $\mathbf{T}_{8}$ & 149 & 338 & 1582 & 2070 \\
\hline $\mathrm{CD}(\mathrm{P}<0.05)$ & 74.6 & 102.3 & 186.2 & 285.1 \\
\hline $\operatorname{SEM}( \pm)$ & 9.93 & 19 & 3.6 & 3.8 \\
\hline CV (\%) & 19.2 & 13.9 & 9.7 & 7.4 \\
\hline
\end{tabular}


Table.5 Effect of various treatments on yield contributing characters of rice at harvest

\begin{tabular}{|c|c|c|c|c|c|c|c|}
\hline Treatment & $\begin{array}{c}\text { No. of } \\
\text { Productive } \\
\text { tillers/plant }\end{array}$ & $\begin{array}{c}\text { No. of } \\
\text { grains/plant }\end{array}$ & $\begin{array}{l}\text { Panicle } \\
\text { Length } \\
(\mathbf{c m})\end{array}$ & $\begin{array}{c}\mathbf{1 0 0 0} \\
\text { grain } \\
\text { weight } \\
\mathbf{( g )}\end{array}$ & $\begin{array}{l}\text { Grain } \\
\text { yield } \\
\text { (t/ha) }\end{array}$ & $\begin{array}{l}\text { Straw } \\
\text { yield } \\
\text { (t/ha) }\end{array}$ & $\begin{array}{c}\text { Harvesting } \\
\text { index } \\
(\boldsymbol{\%})\end{array}$ \\
\hline $\mathbf{T}_{\mathbf{1}}$ & 8 & 642 & 25.6 & 38.1 & 6.1 & 8.6 & $\mathbf{4 1 . 5}$ \\
\hline $\mathbf{T}_{\mathbf{2}}$ & 9 & 697 & 26 & 39.2 & 6.5 & 9.2 & $\mathbf{4 1 . 4}$ \\
\hline $\mathbf{T}_{\mathbf{3}}$ & 7 & 704 & 29.2 & 39.8 & 6.9 & 9.3 & $\mathbf{4 2 . 5}$ \\
\hline $\mathbf{T}_{\mathbf{4}}$ & 8 & 631 & 25.06 & 36.2 & 5.4 & 9.8 & $\mathbf{3 5 . 5}$ \\
\hline $\mathbf{T}_{\mathbf{5}}$ & 6 & 651 & 25.3 & 36.9 & 6.0 & 10.4 & $\mathbf{3 6 . 5}$ \\
\hline $\mathbf{T}_{\mathbf{6}}$ & 7 & 679 & 25.1 & 38.3 & 6.4 & 10.8 & $\mathbf{3 7 . 2}$ \\
\hline $\mathbf{T}_{\mathbf{7}}$ & 7 & 743 & 26.06 & 40.2 & 7.1 & 11.1 & $\mathbf{3 9 . 0 1}$ \\
\hline $\mathbf{T}_{\mathbf{8}}$ & 10 & 812 & 29.7 & 40.8 & 7.9 & 12.1 & $\mathbf{3 9 . 5}$ \\
\hline $\mathbf{C D}(\mathbf{P}<\mathbf{0 . 5}$ & 1.2 & 213.2 & 2.8 & 3.8 & 1.4 & 1.6 & $\mathbf{9 . 2}$ \\
\hline $\mathbf{S E M}(\mathbf{\pm})$ & 0.50 & 21.64 & 0.84 & 0.729 & 0.26 & 0.42 & $\mathbf{1 . 0 4}$ \\
\hline $\mathbf{C V}(\mathbf{\%})$ & $\mathbf{1 8 . 2}$ & $\mathbf{8 . 8}$ & $\mathbf{9 . 0 2}$ & $\mathbf{5 . 4}$ & $\mathbf{9 . 9}$ & $\mathbf{1 1 . 9}$ & $\mathbf{6 . 9}$ \\
\hline
\end{tabular}

Table.6 Water use efficiency of rice under different level of irrigation

\begin{tabular}{|c|c|c|c|c|c|c|}
\hline Treatment & $\begin{array}{c}\text { Total } \\
\text { irrigation } \\
\text { water } \\
\text { applied } \\
(\mathbf{m m})\end{array}$ & $\begin{array}{c}\text { Effective } \\
\text { rainfall } \\
(\mathbf{m m})\end{array}$ & $\begin{array}{c}\text { Total } \\
\text { amount } \\
\text { of water } \\
\text { applied } \\
(\mathbf{m m})\end{array}$ & $\begin{array}{c}\text { Total } \\
\text { Water saving } \\
(\%)\end{array}$ & $\begin{array}{l}\text { Water use } \\
\text { efficiency } \\
\text { (t/ha-cm) }\end{array}$ & $\begin{array}{c}\text { Amount of } \\
\text { water to } \\
\text { produce } \\
\text { unit yield } \\
(1 / \mathrm{kg})\end{array}$ \\
\hline$T_{1}$ & 261.2 & 796 & 1057.2 & 75.7 & 0.0576 & 1733 \\
\hline $\mathbf{T}_{2}$ & 313.4 & 796 & 1109.4 & 74.5 & 0.0585 & 1706 \\
\hline$T_{3}$ & 313.4 & 796 & 1109.4 & 74.5 & 0.0621 & 1607 \\
\hline $\mathbf{T}_{4}$ & 195.8 & 796 & 991.8 & 77.2 & 0.0544 & 1836 \\
\hline $\mathbf{T}_{5}$ & 235.1 & 796 & 1031.1 & 76.3 & 0.0581 & 1718 \\
\hline$T_{6}$ & 235.1 & 796 & 1031.1 & 76.3 & 0.0620 & 1611 \\
\hline $\mathbf{T}_{7}$ & 2222 & 796 & 3018 & 30.6 & 0.0235 & 4250 \\
\hline $\mathbf{T}_{8}$ & 3555.5 & 796 & 4351.5 & & 0.0181 & 5508 \\
\hline CD $(P<0.5)$ & & & & & 0.21 & \\
\hline SEM ( \pm$)$ & & & & & 0.075 & \\
\hline CV (\%) & & & & & 17.4 & \\
\hline
\end{tabular}

Fig.1 Effect of different levels of irrigation on plant height of rice crop

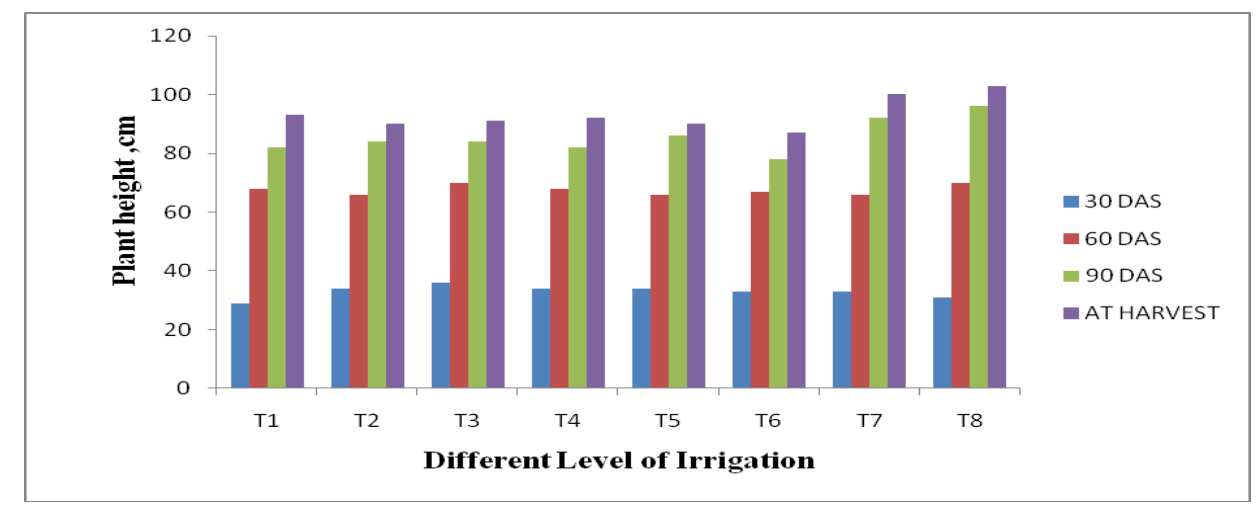


Fig.2 Effect of different levels of irrigation on tillers per plant for rice crop

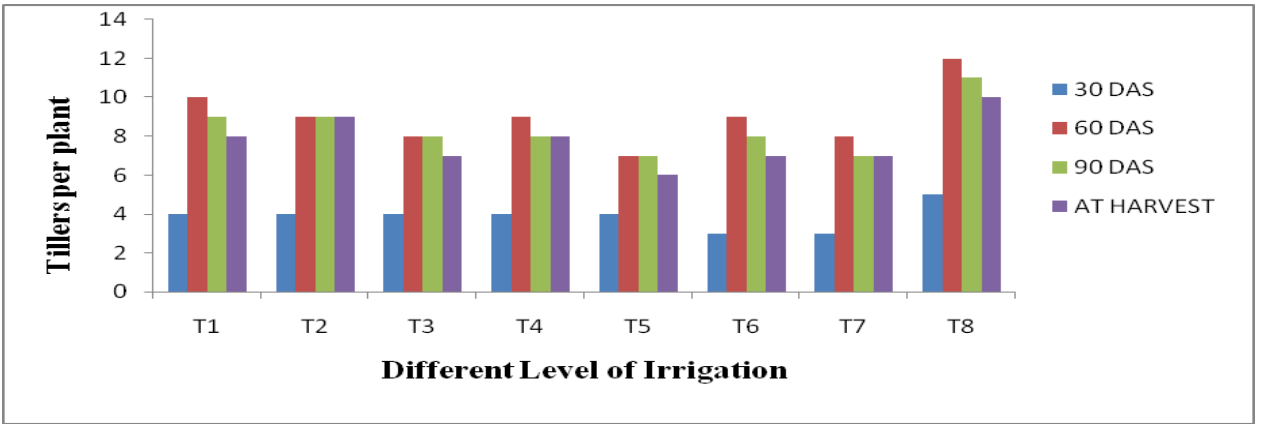

Fig.3 Effect of different levels of irrigation on leaf area index (LAI) for rice crop

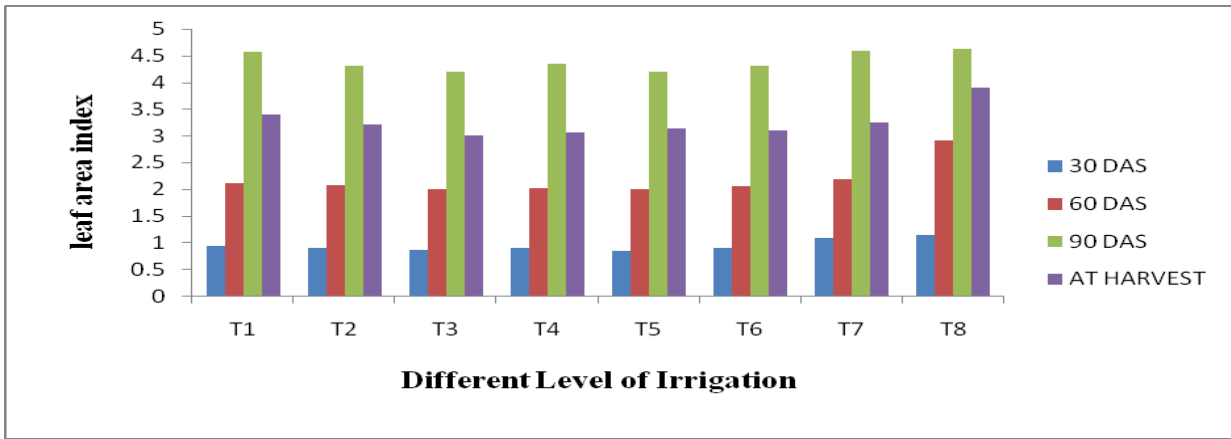

Fig.4 Effect of different levels of irrigation on plant dry matter for rice crop

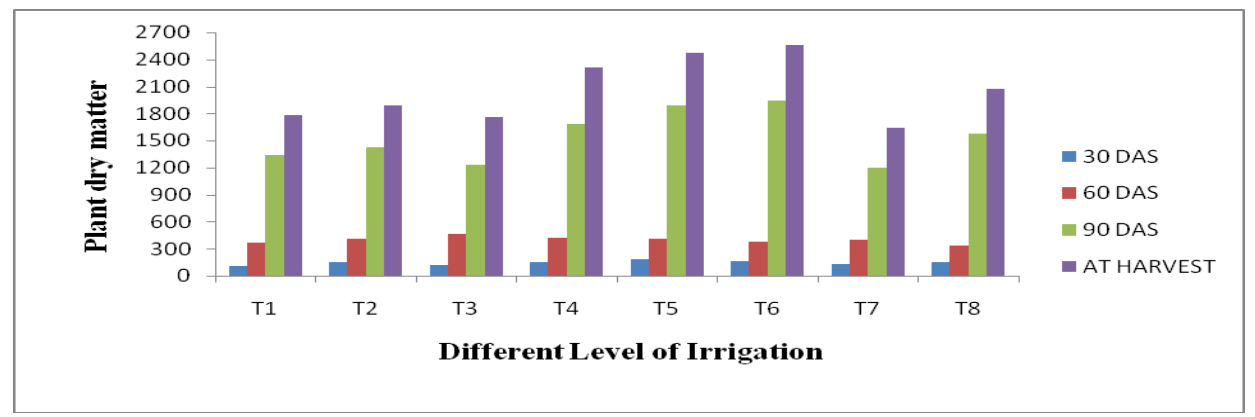

Plate.1 Rice crop under drip irrigation at 15 and 30 DAS
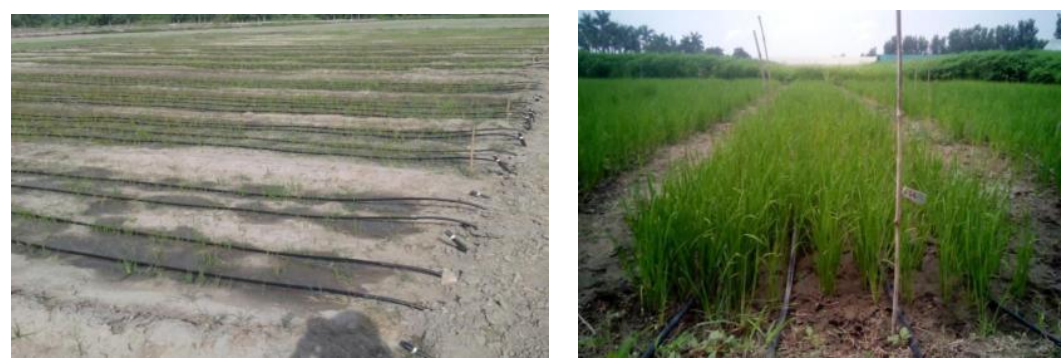

Plate. 2 Rice crop at 90 DAS and at harvest 


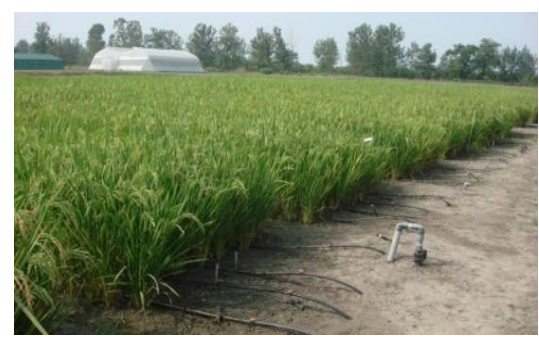

The highest leaf area index at 30 DAS was recorded for the treatment $\mathrm{T}_{8}\left(1.16 \mathrm{~m}^{2} \mathrm{~m}^{-2}\right)$ followed by $\mathrm{T}_{7}\left(1.1 \mathrm{~m}^{2} \mathrm{~m}^{-2}\right)$. AT 60,90 , and at harvest the highest LAI was recorded again in $\mathrm{T}_{8}\left(4.78 \mathrm{~m}^{2} \mathrm{~m}^{-2}\right)$ followed by $\mathrm{T}_{6}\left(4.6 \mathrm{~m}^{2} \mathrm{~m}\right.$ 2). Thus, result showed that TPR with submerged soil irrigation was significantly superior to DSR under drip irrigation. In case of plant dry matter the effect of different level of irrigation was found to be significant at all different DAS. At 30, 60 and 90 DAS the plant dry matter was recorded maximum for treatment $\mathrm{T}_{5}\left(182 \mathrm{gm}^{-2}\right), \mathrm{T}_{3}\left(463 \mathrm{gm}^{-2}\right)$ and $\mathrm{T}_{6}$ $\left(1946 \mathrm{gm}^{-2}\right)$, respectively. At harvest, the plant dry matter was found to be highest for the treatment $\mathrm{T}_{8}\left(2070 \mathrm{gm}^{-2}\right)$. The number of productive tillers/hill and panicle length were recorded highest for treatment $\mathrm{T}_{8}$ followed by $\mathrm{T}_{2}$ and $\mathrm{T}_{7}$.

The analysis of the data revealed that the number of panicles and grains per plant were recorded highest for the treatment $\mathrm{T}_{8}$ followed by $T_{7}$ and $T_{3}$. The weight of 1000 grains was highest for treatment $\mathrm{T}_{8}$ with a value of 40.8 gm followed by $T_{3}$ and $T_{2}$. The grain yield was observed maximum for the treatment $T_{8}$ (7.9 t/ha) followed by treatment $T_{7}(7.1 \mathrm{t} / \mathrm{ha})$ and treatment $\mathrm{T}_{3}(6.9 \mathrm{t} / \mathrm{ha})$ and minimum for treatment $\mathrm{T}_{4}(5.4 \mathrm{t} / \mathrm{ha})$. The straw yield was observed maximum for the treatment $\mathrm{T}_{8}(12.1$ $\mathrm{t} / \mathrm{ha}$ ) followed by treatment $\mathrm{T}_{7}(11.1 \mathrm{t} / \mathrm{ha})$ and the minimum for $\mathrm{T}_{1}(8.6 \mathrm{t} / \mathrm{ha})$.In this study harvesting index was recorded highest for the treatment $\mathrm{T}_{3}(42.5 \%)$ and lowest for treatment $\mathrm{T}_{4}(35.5 \%)$.

The water saving over submerged soil

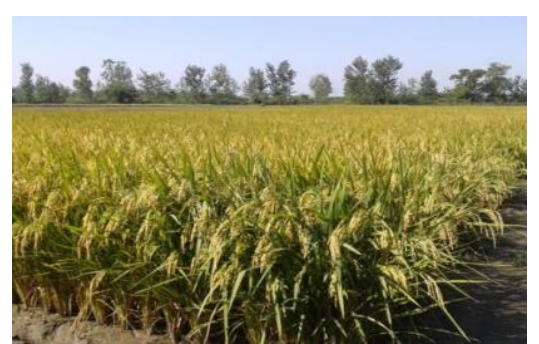

irrigation under surface irrigation (TPR) was found to be highest for treatment $\mathrm{T}_{4}$ with a value of $94.4 \%$, followed by treatment $\mathrm{T}_{1}$ with a value of $92.6 \%$ and lowest for treatment for $\mathrm{T}_{7}$ with a value of $37.4 \%$. During entire growing period of crop the total irrigation water applied for the treatments $T_{1}$, $\mathrm{T}_{2}, \mathrm{~T}_{4}, \mathrm{~T}_{5}$ under surface drip irrigation and for the treatments $\mathrm{T}_{3}, \mathrm{~T}_{6}$, under subsurface drip irrigation was 261.2, 313.4, 195.8, 235.1 and $313.4,235.1 \mathrm{~mm}$, respectively. Similarly total irrigation water applied for the treatments $T_{7}$ and $\mathrm{T}_{8}$ under surface irrigation was 2222 and $3555.5 \mathrm{~mm}$, respectively The water use efficiency was found to be highest for treatment $T_{3}$, followed by treatment $T_{6}$ and lowest for treatment $\mathrm{T}_{8}$. In this study the amount of water needed to grow one $\mathrm{kg}$ of rice was found to be lowest for treatment $T_{3}$ with a value of 1603 litres of water, followed by treatment $\mathrm{T}_{6}$ with a value of 1611 litres of water and highest for treatment $\mathrm{T}_{8}$ with a value of 5508 litres of water.

\section{References}

Abedinpour, M., Sarangi, A., Rajput, T.B.S., Singh, M., Pathak, H. and Ahmad, T. 2012. Performance evaluation of Aqua Crop model for maize crop in a semiarid environment. Agricultural Water Management, 110: 55-66.

Andarziana, B., Bannayanb, M., Stedutoc, P., Mazraeha, H., Baratid, M.E., Baratie, M.A. and Rahnamaa, A. 2011. Validation and testing of the Aqua Crop model under full and deficit 
irrigated wheat production in Iran. Agricultural Water Management, 100: $1-8$.

Cinaj, M. and Grazhdani, S. 2015. Validation of Aqua Crop model in the simulation of sugar beet production under different water regimes in southeastern Albania. International Journal of Engineering Science and Innovative Technology (IJESIT), Volume 4. and Mojtaba, R. 2015. Simulation of rice yield under water and salinity stress in rasht area using Aqua Crop model. Journal Technology (Science and Engineering), 76: 21-28.

El-Rahman, G. Abd. 2009. Water Use Efficiency of Wheat under Drip Irrigation Systems at Al Maghara Area, North Sinai, Egypt. AmericanEurasian Journal Agriculture \& Environment Science, 5: 664 - 670.

Ebrahim, A., Hamidreza, A.A., Aimrun, W.

\section{How to cite this article:}

Vikas Sharma, Priyanka Gunjan, Yadvendra Pal Singh and Singh, P.K. 2019. Growth, Yield and Yield Contributing Factors of Rice Crop as Influenced by Different Level and Methods of Irrigation in Tarai Region of Uttarakhand, India. Int.J.Curr.Microbiol.App.Sci. 8(04): 10881098. doi: https://doi.org/10.20546/ijcmas.2019.804.126 